УДК $616-056+616.329-007.43-089.12-089.168$

$\mathrm{DOI}$

(С) О. Ю. УСЕНКО, Б. М. КОНДРАТЕНКО

ДУ “Національний інститут хірургії та трансплантології ім. О. О. Шалімова" НАМН України

\title{
Баріатрична операція як шлях покращення якості життя в лікуванні хворих із післяопераційною вентральною грижею та супутнім морбідним ожирінням
}

\author{
O. YU. USENKO, B. M. KONDRATENKO \\ SI "National Institute of Surgery and Transplantation by O. O. Shalimov" of NAMS of Ukraine
}

\section{BARIATRIC SURGERY AS A WAY TO IMPROVE THE QUALITY OF LIFE IN PATIENTS WITH INCISIONAL HERNIA AND ASSOCIATED WITH MORBID OBESITY}

\begin{abstract}
У роботі представлено результати хірургічного лікування 73 хворих із післяопераційною вентральною грижею (ПОВГ) та супутнім морбідним ожирінням (МО). У 31 пацієнта лікування було поділено на два етапи: перший - баріатрична операція (БО), другий - відстрочена герніопластика; у 9 хворих герніопластику було виконано симультанно 3 БО; 33 пацієнтам було виконано лише герніопластику. За результатами дослідження встановлено високу ефективність лікування хворих при двохетапному підході, про що свідчили зменшення частоти післяопераційних ускладнень 3 36,4 до 9,7 \% та значне покращення рівня якості життя (в 2,1 раза) у віддаленому післяопераційному періоді порівняно 3 доопераційним.

This study presents the results of surgical treatment of 73 patients with postoperative ventral hernia (POVH) and related morbid obesity (MO). In 31 patients the treatment was divided into two stages: first bariatric surgery (BS), the second - delayed hernioplasty; to 9 patients hernioplasty was performed simultaneous with BS; 33 patients underwent only hernioplasty. The study found high effectiveness of treatment for a two-stage approach, as evidenced by reduced frequency of postoperative complications from $36.4 \%$ to $9.7 \%$ and a significant improvement in quality of life ( 2.1 times) in remote postoperative period compared with preoperative.
\end{abstract}

Постановка проблеми і аналіз останніх досліджень та публікацій. Серед хворих, які страждають від ПОВГ, від 50 до 70 \% осіб мають різний ступінь ожиріння, серед них від морбідного страждають 25 \% [1]. Результати лікування таких хворих, незважаючи на впровадження сучасних методик герніопластики та синтетичних матеріалів, залишаються незадовільними, за свідченням різних авторів, частота рецидивів може сягати 64 \% [1]. Якість життя у віддаленому післяопераційному періоді герніопластики у більшості випадків залишається на доопераційному рівні, а іноді й нижчою, що зумовлено не тільки наявністю рецидиву ПОВГ, а й подальшим прогресуванням як самого ожиріння, так і супутніх захворювань [2].

В Україні від ожиріння страждають близько 35 \% населення, за даними дослідників, кількість таких хворих невпинно зростає. Ожиріння супроводжується великою кількістю супутніх захворювань, в тому числі й тих, які потребують операційного лікування [2]. Ризик виникнення ПОВГ у хворих на ожиріння становить 25 \% при планових операційних втручаннях, що потребують лапаротомії, та 40 \% у разі екстреної лапаротомії [3, 4, 5, 6].

Консервативне лікування у 90 \% хворих на МО малоефективне [2, 7, 8, 9]. В останні десятиріччя бурхливого розвитку набув окремий напрямок хірургії - баріатрична хірургія, яка дала хворим на МО шанс радикально змінити своє життя $[2,9]$. Застосування баріатричних методик у комплексному лікуванні хворих із ПОВГ та супутнім МО з оцінкою віддалених результатів лікування стало метою нашого дослідження.

Матеріали і методи. В основу дослідження покладено результати обстеження й хірургічного лікування 73 хворих із ПОВГ та супутнім МО, яким виконано операцію - пластику передньої черевної стінки у період з 2000 до 2015 р. Середній вік хворих становив $(45,4 \pm 8,3)$ року (від 29 до 60 років), 58 (79,5 \%) пацієнтів були працездатного віку. Середня маса тіла складала $(141,5 \pm 29,5)$ кг (від 108 до 180 кг), середній індекс маси тіла (IMT)

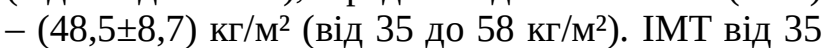


до 45 кг/м² відзначено у 26 \% пацієнтів, від 45 до 55 кг $/ \mathrm{M}^{2}$ - у $49 \%$, від 55 до 58 кг $/ \mathrm{M}^{2}$ - в $11 \%$. В загальній групі переважали жінки - 59 (80,8 \%), чоловіків було 14 (19,2 \%). Розподіл хворих за характером дефекту передньої черевної стінки проводили згідно з інтраопераційною класифікацією Chevrel-Ratz (2000), всі хворі мали серединну локалізацію грижі $\left(\mathrm{M}_{1-5}\right)$, ширина грижових воріт коливалась від 5 до 18 см $\left(\mathrm{W}_{2-4}\right)$, частота рецидивів $\mathrm{R}_{0-2}$. У роботі використовували розширену класифікацію Міжнародної групи з вивчення ожиріння BOO3 (IOTF WHO, 1997), за якою ожиріння II ступеня діагностували за величини IMT 35,0-

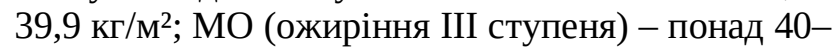

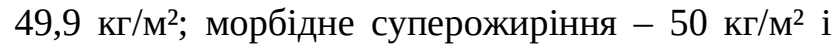
більше. Для вирішення поставлених завдань загальну групу хворих розподілили на групу порівняння та основну групу залежно від застосованої хірургічної тактики лікування. За показниками ожиріння: масою тіла, індексом маси тіла (IMT), ступенем ожиріння, індексом талія/стегно (ITC) групи дослідження були зіставні. До групи порівняння увійшли 33 (45,2 \%) пацієнти, яким було виконано лише герніопластику. До основної групи увійшли 40 пацієнтів, які були поділені на дві підгрупи. Підгрупа А, 31 (42,5 \%) хворий, яким лікування було розподілено на два етапи: перший - БО, другий - відстрочена герніопластика. Підгрупа Б, 9 (12,3 \%) пацієнтів, у яких БО виконано одномоментно (симультанно) з герніопластикою. Бандажування шлунка виконано у 25 (62,5 \%) пацієнтів, шунтування шлунка за Fobi-Capella - в 11 (27,5 \%) хворих, біліопанкреатичне шунтування за N. Scopinaro - в 4 (10 \%) осіб. За методикою Rives-Stoppa прооперовано 32 (43,8 \%) хвоpих, за Rives-Stoppa з неповним укриттям ППС 30 (41,1 \%), за Ramires з ППС - 11 (15,1 \%). Всім хворим проведено комплексне обстеження: з використанням загальноприйнятих методів. Якість життя оцінювали за опитувальником SF-36 до і через 12 місяців після операції. Після виписування всі пацієнти перебували під диспансерним спостереженням, огляд проводили на 6-й, 12-й місяці після виписування та на 36-й місяць. Повторне обстеження включало аналіз антропометричних параметрів і спеціальні методи дослідження (функції зовнішнього дихання, кислотно-основного стану (КОС) та газообміну).

Результати досліджень та їх обговорення. У більшості (83,4 \%) пацієнтів діагностовано одне або декілька супутніх захворювань різної тяжкості. Найбільш часто виявляли артеріальну гіпертензію - у 58,9 \% пацієнтів, ЦД II типу або пору- шення толерантності до глюкози - у 37 \% хворих, дисліпідемію - у 24,3 \% пацієнтів, метаболічний синдром - у 19,5 \% осіб, синдром сонного апное - у 19,1 \% хворих. У 72,5 \% пацієнтів за результатами показників кислотно-основного стану та газообміну діагностовано метаболічні порушення у вигляді ацидозу та змішаного ацидозу. Ожиріння та супутні захворювання спричинили втрату працездатності у 63,4 \% пацієнтів, 3 приводу чого у 33,7 \% з них встановлено інвалідність. Тяжкість початкового фізичного стану в підгрупі А у 67,7 \% хворих відповідала III класу за ASA, таким чином, підгрупа А була значно обтяжена за цим показником. Водночас у підгрупі Б пацієнтів із III класом за ASA не виявлено, в порівняльній 13,5 \% хворих мали III клас анестезіологічного ризику за ASA, різниця за цим показником статистично достовірна $(\mathrm{P}<0,05)$.

У хворих основної групи максимальну втрату надлишку маси тіла (ВНМТ) після обох операцій встановлено через 2 роки. Тому склад основної групи на кінцевому терміні спостереження після баріатричної операції (БО) за показником IMT мав такий вигляд: 7 (100 \%) хворих вийшли із розряду суперожиріння, 8 (20,0 \%) пацієнтів 3 розряду ожиріння та мали надлишкову масу тіла, І ст. ожиріння мали 13 (32,5 \%) хворих, ІІ ст. 12 (30,0 \%), лише у 7 (17,5 \%) - III ст. ожиріння. Враховуючи клінічну значимість супутньої патології для подальшого лікування хворих основної групи, в ході нашого дослідження був проведений клініко-лабораторний скринінг основних супутніх захворювань, результати якого відображено в таблиці 1.

Стійку нормалізацію артеріального тиску без застосування антигіпертензивних препаратів через 24 місяці відзначено у 85,3 \% пацієнтів. Синдром сонного апное зник майже в усіх хворих. Нормалізацію ліпідного спектра виявлено у 53,7 \% пацієнтів. Окремо слід наголосити, що покращення та зникнення метаболічного синдрому відбувалось шляхом усунення його основних складових: абдомінального ожиріння, артеріальної гіпертензії, ЦД та дисліпідемії, що відзначено у 78,8 \% хворих. Разом з тим, ми не спостерігали погіршення перебігу зазначених супутніх захворювань. При визначенні класу анестезіологічного ризику за ASA у хворих підгрупи А на початку лікування встановлено, що ризик анестезіологічного забезпечення у 21 (67,7 \%) пацієнта визначався як ASA III, у 10 (32,3\%) хворих - ASA II. Отже, підгрупа А основної групи на початку лікування була значно обтяжена за класом анестезіологічного ризику. Оцінка фізичного стану цих хворих після БО показала, що 
Таблиця 1. Вплив БО на перебіг супутніх захворювань через 24 місяці після втручання

\begin{tabular}{|c|c|c|c|c|c|c|c|c|c|c|}
\hline \multirow[t]{2}{*}{ Захворювання } & \multicolumn{2}{|c|}{ Погіршення } & \multicolumn{2}{|c|}{ Без змін } & \multicolumn{2}{|c|}{ Покращення } & \multicolumn{2}{|c|}{ Усунення } & \multicolumn{2}{|c|}{$\begin{array}{c}\text { Разом покращення } \\
\text { та усунення }\end{array}$} \\
\hline & абс. & $\%$ & абс. & $\%$ & абс. & $\%$ & абс. & $\%$ & абс. & $\%$ \\
\hline $\begin{array}{l}\text { Артеріальна } \\
\text { гіпертензія }(\mathrm{n}=38)\end{array}$ & - & - & 6 & 14,7 & 22 & 58 & 10 & 27,3 & 32,4 & 85,3 \\
\hline ЦД II типу (n=19) & - & - & 5 & 26,3 & 8 & 42,2 & 6 & 31,5 & 14,0 & 73,7 \\
\hline Дисліпідемія (n=33) & - & - & 15 & 46,3 & 10 & 31,7 & 7 & 22 & 17,7 & 53,7 \\
\hline $\begin{array}{l}\text { Метаболічний } \\
\text { синдром (n=29) }\end{array}$ & - & - & 4 & 15 & 18 & 63,3 & 4 & 15,2 & 22,8 & 78,5 \\
\hline $\begin{array}{l}\text { Синдром сонного } \\
\text { апное }(n=13)\end{array}$ & - & - & - & - & 7 & 52,9 & 5 & 42,2 & 12,4 & 95,1 \\
\hline
\end{tabular}

Примітка. В одного пацієнта могло бути два супутніх захворювання або більше.

характер групи за частотним показником класу ASA змінився (рис. 1). Із представленої діаграми видно, що в термін 24 місяці після БО в підгрупі А у більшості хворих зменшився клас ризику за ASA, значна частина хворих перейшла в розряд ASA I, хворих з ASA III не відмічено.

Структура післяопераційних ускладнень була представлена специфічними (рановими) ускладненнями (серомами, нагноєнням, інфільтратом, гематомою) та неспецифічними (пневмоніями, прогресуванням дихальної і серцевої недостатності та гострою спайковою непрохідністю кишечнику).

Порівняльний аналіз кількості післяопераційних ускладнень показав, що в підгрупі А основної групи, в якій хворим алогерніопластику було виконано другим етапом, достовірно менша кількість післяопераційних ускладнень - 3 (9,7 \%) і 13 (39,4 \%) у групі порівняння, де лікування рубцевої грижі було виконано на тлі ожиріння $\left(x^{2}=6,01\right.$, p=0,02). Слід зазначити, що в підгрупі Б основної групи після виконання симультанної ГП та БО було визначено тенденцію до високої частоти післяопераційних ускладнень, які відмічено у 6 (66,7 \%) пацієнтів. Із 33 хворих групи порівняння віддалені результати простежено в строки 1 рік і більше - у 100 \%, з них результати простежено до 2 років - у 29 (90 \%) пацієнтів і до 3 років - у 21 (38,3 \%) хворого. У групі порівняння наявність рецидиву грижового випинання виявлено у 12 (36,4 \%) осіб. Середній строк рецидиву грижового випинання склав $(7,9 \pm 0,7)$ місяця. Із 40 хворих основної групи віддалені результати простежено в строки 1 рік і більше - в 100 \%, до 2 років - у 34 (85 \%), до 3 років - у 28 (70 \%). У підгрупі А основної групи було виявлено рецидив грижі у 3 (9,7 \%) пацієнтів, в підгрупі Б - у 6 (66,7 \%). Середній строк рецидиву грижового випинання склав $(9,8 \pm 0,5)$ місяця.

Аналіз результатів дослідження, яке оцінювало показники якості життя у хворих обох груп за допомогою опитувальника SF-36, не встановив істотних відмінностей між станом до операції в основній і порівняльній групах. Інтегральний показник якості життя (ІПЯЖ) у хворих порівняльної групи до герніопластики в середньому становив $(42,36 \pm 3,2)$ бала, а через 24 місяці після операції істотно не відрізнявся від доопераційно-

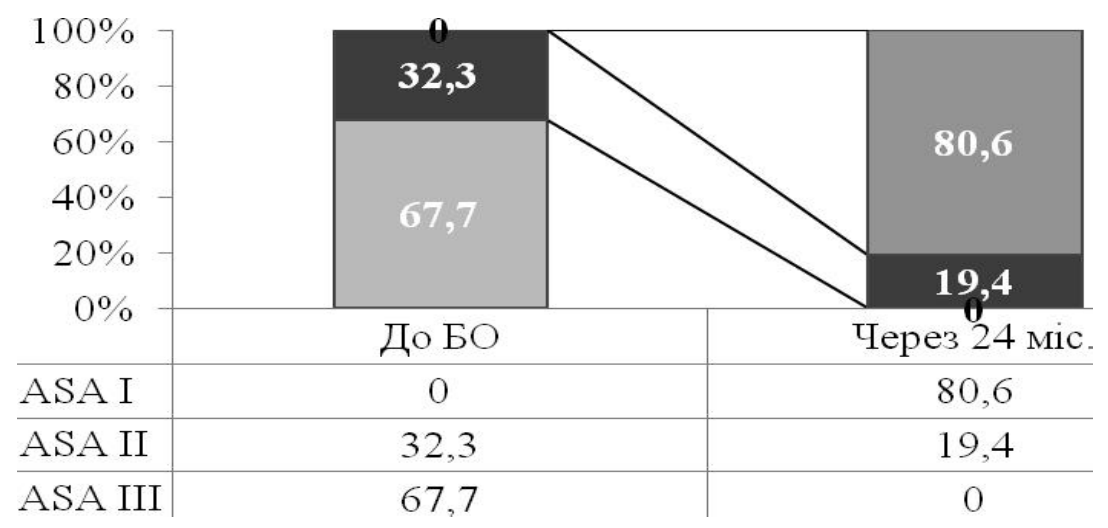

Рис. 1. Порівняльна характеристика хворих підгрупи А основної групи за класом ризику ASA до та через 24 місяці після баріатричного втручання. 
го - $(47,09 \pm 3,3)$ бала $(\mathrm{p}<0,05)$. В основній же групі у хворих, яким було виконано герніопластику другим етапом після баріатричної операції, через 24 місяці відзначено поліпшення якості життя за всіма компонентами дослідження ( $<0,01 \%)$. Так, ІПЯЖ у хворих підгрупи А через 24 місяці після герніопластики перевищував цей показник у хворих порівняльної групи в 1,8 раза. Показник ІПЯЖ підгрупи Б перевищував такий у групі порівняння в 1,7 раза.

Співвідношення показників ІПЯЖ у хворих груп дослідження до початку лікування та через 24 місяці після герніопластики відображено на діаграмі (рис. 2).

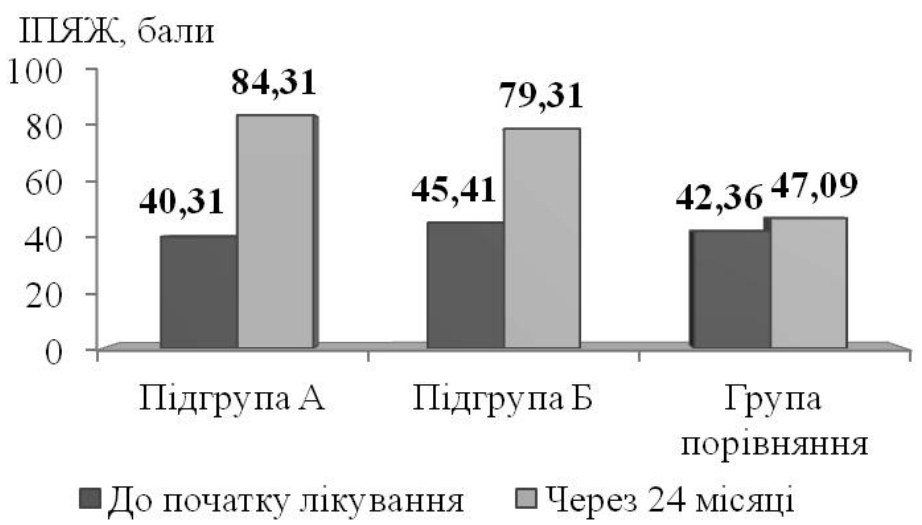

Рис. 2. Характеристика ІПЯЖ у хворих груп дослідження на початку лікування та через 24 місяці після герніопластики.

Узагальнюючи результати лікування хворих порівняльної групи, слід зазначити, що при лікуванні ПОВГ на тлі ожиріння відзначали високу частоту випадків неефективного лікування, що виражалося в 36,4 \% рецидивів гриж черевної стінки. У 14 (42,4 \%) пацієнтів, незважаючи на відсутність рецидиву грижі, було відмічено наявність больового синдрому в ділянці передньої черевної стінки, наявність значної надмірної маси і пов'язаних з цим медичних, психологічних та соціальних проблем, що не дозволило говорити про кардинальну зміну ситуації для них та зміну якості життя в кращий бік, що підтвердило дослідження за опитувальником SF-36. У підсумку незадовільні результати у порівняльній групі хворих були визнані в 55 \% осіб. У пацієнтів, які уникли

\section{СПИСОК ЛІТЕРАТУРИ}

1. Яшков Ю. И. Хирургическое лечение ожирения и метаболических нарушений / Ю. И. Яшков, М. С. Синеокая // Материалы Пятого российского симпозиума с международным участием. - Самара, 2009. - С. 90.

2. Лаврик А. С. Хірургічне лікування ожиріння / А. С. Лаврик, О. С. Тивончук, О. А. Лаврик // Здоров’я України. - 2013. - № 1. - C. 10-11.

3. Лечение гигантских послеоперационных вентральных грыж у пациентов с морбидным ожирением / К. М. Аутло, А. Л. Янин, Е. В. Кручинина, В. В. Иванов // Материалы Пятого российского симпозиума с международным участием. Самара, 2009. - С. 20.

4. Образование послеоперационной грыжи у больных на фоне ожирения / О. В. Галимов, В. О. Ханов, А. В. Шкундин [и др.] // Клінічна хірургія. - 2010. - № 8 (809) - С. 8. рецидиву захворювання, рівень якості життя продовжував залишатися на незадовільному рівні або знижувався, внаслідок прогресування ожиріння та асоційованих із ним захворювань.

Висновки. 1. Застосування БО в комплексному лікуванні хворих із ПОВГ та супутнім МО суттєво полегшує перебіг основних супутніх захворювань.

2. Впровадження двохетапної тактики лікування хворих на ПОВГ із супутнім МО дозволило знизити рівень ранових ускладнень в 4,1 раза, неспецифічних - в 5,9 раза, зменшити частоту рецидиву ПОВГ у 3,8 раза та покращити якість життя у віддаленому періоді герніопластики в 2,1 раза (за опитувальником MOS SF-36).

5. Міліца М. М. Грижа і грижова хвороба: новий погляд на патогенез / М. М. Міліца, Ю. Д. Торопов, К. Н. Міліца // Клінічна хірургія. - 2009. - № 1. - С. 35-37.

6. Newman M. I. The Hole in the Wall // M. I. Newman // Bariatric Times. - 2011. - Vol. 8, № 4. - P. 16-17.

7. Raghavendra S. Management of ventral hernias in bariatric surgery / S. Raghavendra, P. Gentileschi, S. Kini // Surg. Obes. Relat. Dis. - 2011. - Vol. 7. - P. 110-116.

8. Laparoscopic ventral hernia repair (LVHR) in morbidly obese patients / Z. Tsereteli, B. Pryor, B. Heniford [et al.] // Hernia. 2008. - Vol. 12, № 3. - P. 233-238.

9. Staged hernia repair preceded by gastric bypass for the treatment of morbidly obese patients with complex ventral hernias / W. Newcomb, J. Polhill, A. Chen [et al.] // Hernia. - 2008. - Vol. 12, № 5. - P. 465-469.

Отримано 12.10.15 